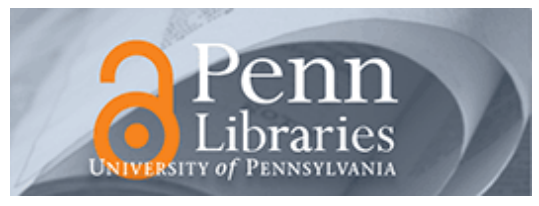

Studies in Visual Communication

Volume 10

Issue 2 Spring 1984

Article 2

1984

\title{
Art and Communications in the West Bank: Visual Dimensions of Palestinian Nation Building
}

Dov Shinar

\section{Recommended Citation}

Shinar, D. (1984). Art and Communications in the West Bank: Visual Dimensions of Palestinian Nation Building. 10 (2), 2-15. Retrieved from https://repository.upenn.edu/svc/vol10/iss2/2

This paper is posted at ScholarlyCommons. https://repository.upenn.edu/svc/vol10/iss2/2

For more information, please contact repository@pobox.upenn.edu. 
Art and Communications in the West Bank: Visual Dimensions of Palestinian Nation Building 


\section{Art and Communications in the West Bank: Visual Dimensions of Palestinian Nation Building}

\section{Dov Shinar}

\section{The Context}

"The Palestinian movement," a respected analyst in the Israeli Press recently wrote, "led in the last 15 years by the PLO, has built a self-conscious nation

there is no point in using the worn-out argument that the Palestinians have no cultural, religious, historic or linguistic uniqueness. ... In terms of nationbuilding, the Palestinians have had none but achievements during these years" (Ben-Porat 1983).

Indeed, denial of the very existence of a Palestinian national entity, voiced in earlier years by Israeli Prime Ministers and members of the Knesset, has become as unacceptable as formulas designed to solve the "Palestinian problem" by means of encouraging immigration to Arab countries, or by directly or indirectly taking over the East Bank. Such views have been replaced by more realistic positions, adopted even by outspoken hardliners, who have pragmatically and officially recognized "the legitimate rights of the Palestinian people"

Gone also are the days when a Jordanian king could issue a decree to forbid the use of the word "Palestine" in official documents ${ }^{2}$ or when the regime sought to eliminate West Bank separatist trends by means of lip service, financial support, or bloodshed. Claims for full integration in the kingdom have lost momentum in the entire Arab world, to be replaced by formulas and scenarios which emphasize various shades of Palestinian self-expression and self-determination. The sporadic and ineffective expressions of Palestinian nationalism in the pre-1967 West Bankwhen Palestinians had been hindered by Jordanian annexation from establishing independent political authority, had been dependent on the kingdom for allocation of resources, and relied heavily on Pan-Arab and Pan-Islamic symbols (Mishal 1978) - and the anomic reactions caused by defeat and occupation have crystallized into the revival of a full-fledged national movement, featuring more consistent policies

\footnotetext{
Dov Shinar is a member of the Communications Institute, Hebrew University of Jerusalem. He has done research and served as international consultant on communications and national development, coauthored (with Elihu Katz and George Wedell) Broadcasting in the Third World (Harvard University Press, 1977), and developed $R \& D$ programs on communications with social minorities. He is currently engaged in research on alternative media and on the uses of communication in social development. This article is part of a larger study on communications in the West Bank, conducted with the assistance of Ahmad Natur and Anthony Kingsley, both graduate students in the institute.
}

and more rational behavior. Increasingly clearer national objectives have been developing since 1967, from a claim, voiced by the traditional pro-Hashemite elite, for returning to the status-quo-ante, to plans for the establishment of a democratic secular state in all the territory of mandatory Palestine, to de facto recognition of Israel and less radical demands for an independent state in any part of Palestine (see Jiryis 1977; Lesch 1980). Demonstrations of national unity became more effective, finding expression in strikes, rallies, civil disobedience, and petitions, especially after the Yom Kippur War, when a wide pro-PLO consensus developed in the West Bank in response to the perennial question of who was to represent the Palestinian cause. In contrast with Israeli, Jordanian, and international preference for the municipal mayors, the prevailing mood in the West Bank, as from the mid-1970s, may be illustrated by the following statement, made by a Palestinian: "As things are, [the mayors] have to apply to the military governor for spare parts for their municipal vehicles. How can they negotiate peace?"3

Simultaneously with the upsurge in national consciousness, efforts have been made to institutionalize Palestinian nationhood. A noted Israeli academic, who has served as adviser to the occupation authorities, admitted in 1980 that "in the last two years, the PLO jointly with the leadership in the territories ... has been establishing an infrastructure, seen as a basis for a Palestinian state. This has been expressed in the organization of the political community ... the Colleges in the territories . . . Bir-Zeit, near Ramallah A-Najjah in Nablus ... Frères, in Bethlehem the Hebron Islamic Seminary ... the Gaza Islamic College, front-organizations have been established women's, students and others .... also the Press industrial infrastructure ... schools, hospitals and other projects ... construction. ... In order to finance such a wide organizational effort, PLO and Baghdad Conference funds have been pumped into the territories at an estimated 150 million dollars annually.

At the same time, processes of socio-economic change and modernization reveal a restructuring of Palestinian society. This includes, first, a spread of secular values, connected with the humiliating defeat in the Six-Day War and the exposure to Israel, as expressed in the statement made by a Palestinian journalist that these events have "undermined his [the Arab's] belief in his own culture, in his blind faith that Allah's people possess superior qualities to those of the infidels; it has shown Arab Civilization, evaluated in twentieth century terms, to be technologically backward, culturally deprived and politically impotent" (Hamad 1971). Second, it features the disruption of the traditional class system, as a consequence of two factors at least: one is the rise in standard of living and the more equitable distribution of income, linked 
to the provision of jobs in Israel, which affected all, even the unskilled workers, thus weakening the position of notable families and landowners. The other factor is the sense of equality instilled by the legiti mate share of all Palestinians in an emerging national movement led by a radical organization- the PLO Thirdly, it affects the symbolic sphere, including changing patterns of leisure and a "boom in cultural products and events ... beginning with poets ... and going on through exhibitions, posters, jamborees, sports events and the renaissance of traditional embroidery" (Sayegh 1977; quoted in Klug 1979:412). It is finally expressed in the political role of women in the forefront of demonstrations and protest against occupation, together with the expansion of education and job opportunities, legitimized, although reluctantly, because of the circumstances. My Home My Prison, a book by Raymonda Tawil (1979), elaborates in its title as well as its content on the increasingly effective, yet uphill struggle of Palestinian women on two fronts: one, illustrated by Sylvie Mansour's research finding that Palestinian adolescent boys are more militant and feel more frustrated than girls in trying to cope with identity problems, whereas girls rather than boys outline their ideal selves involved in Palestinian resistance (Mansour 1977); the other, illustrated by comments such as "West Bank men who see the free life led by Israeli girls, sometimes even enjoying their company, tend to react when they get back home by being stricter than ever with their own womenfolk". 5

\section{External and Local Constraints}

Palestinian nation building reveals most of the ingredients typical of development processes in the Third World: integration around national objectives, establishment of an institutional infrastructure, cultural renaissance, and socio-economic change. These processes have been influenced by local constraints, resulting from the Israeli presence, from the performance of Arab States, and from international interference, as well as from the emergence of the Palestine Liberation Organization. Israel has served as a model for an overall social outlook that contradicted the previous reality in which, according to a prominent Palestinian, "no attempt has been made anywhere to organize Palestinian self-help through economic and social activity. The only attempt toward organization was political or semi-military" (Shehadeh 1969), thus deeming Palestinian culture as one of "beautiful words... [in which] we still prefer to listen to inciting poetry than to set up a cooperative or any other positive project ... June [1967] happened because our history stood still while the history of the entire world advanced". ${ }^{6}$ Exposure to this model fea- tures Israel's role as a catalyzer, first in the economic sphere, providing opportunities for personal economic advancement and the adoption of more modern materialistic attitudes; secondly, in the West Bank socio cultural restructuration, whereby the loosening of economic bonds between the masses and their overlords contributed to erode their authority and values. Israel has also played an active role in activating political and social tensions which had largely been contained under the Jordanian pre-1967 rule. Israel's very presence and policies of atomization and "increasing the price of resistance"7 have turned the Jewish State into an emotional and behavioral outlet, a "legitimate target" in the struggle for Palestinian nationhood, replacing the more complicated and less convenient struggle against Jordanian and other Moslem brethren. Although these processes did not begin with the inception of Israeli rule, its advent probably accelerated their pace, ascribing to Israel "the role of midwife to a fundamental ... revolution in Arab Palestine" (Shaicovitch 1973).

Resentment, bitterness, and anger, coupled with economic dependence are typical of the Arab States' role in Palestinian nation building. On the one hand, Palestinians see themselves as "the Jews of present times, oppressed by occupation, forsaken by the world, even by our own brethren. ..." This outlook is based upon the disillusionment with Arab commitment and support, as expressed by Jordan in the initial years of occupation, by Syria in the mid-1970s, and by most of the Arab countries, who refused to play host to a defeated PLO, following the 1982 hostilities in Lebanon. The passive role allocated to the Palestinians in the peace process initiated by Anwar Sadat served to emphasize this attitude even more. Thus Arab States may be seen as an additional catalyzer. This role includes, on the other hand, a more positive aspect, that of massive financial support coming from Jordan, Saudi Arabia, the Gulf Emirates, Lybia, and others. Although heavily manipulated, these funds have enabled the Palestinians to make decisive steps in the nation-building process.

The PLO has introduced a revolutionary dimension to the process. Irrespective of its controversial methods and achievements, the organization founded in 1964 by the Arab League as a government-sponsored propaganda agency was gradually transformed into a largely autonomous operation, viewed as consisting of Palestinians, working for Palestinians, and run by Palestinians in representing the concept and reality of a national movement. ${ }^{9}$ The PLO has been active in the formulation and reformulation of objectives, in providing symbolic ideas, motifs, and objects, in inspiring action, in claiming and achieving recognition as the legitimate representative of the Palestinians, in organizing and mobilizing the population, and in instilling a secular and modernizing orientation 


\section{Visual Expressions of the Process}

West Bank artists have given a variety of expressions to the process of Palestinian nation building. The creation and dissemination of visual materials have flourished in the West Bank in recent years. Poetry, literature, and theater were joined by graffiti, calendars, T-shirts, posters, postcards, and paintings to display an impressive array of liberation and development symbols.

Their messages reflect the problems involved in the complex circumstances of Palestinian life, rather than the violent and sometimes racist nature of the verbal and visual pre-1967 Arab propaganda, which concentrated in attacking Israel and the Jews. These circumstances may be understood in terms of nationbuilding dilemmas and their permanent or temporary solutions, which are an outcome of the typical "interplay between institutional change and cultural reconstruction," viewed by Clifford Geertz as the essence of such processes (1975:244). Artistic inclinations in portraying these dilemmas may be inferred from the contents of an exhibit which took place in the summer of 1983 in the Neveh Tsedek Cultural Center in TelAviv, with the objective of exposing Israelis and others to the cultural life of the West Bank (see Figure 1).

Suleiman Mansour, born in 1947 in Bir Zeit, near Ramallah, studied in Israel and exhibited in Moscow, Western Europe, and the United States; he presented mostly political works in oil and ink, such as "Sabra and Shatila," "After the Massacre," "Settlement Crunch," "Censorship," "Civil Administration," and "Flag Burning." Nabil Anani, born in 1947 in Halhoul, near Hebron, studied in Egypt and exhibited in the Middle East and abroad; he presented oil works with a different emphasis, including "Scene from a Palestinian Village" and "Folkloric Decorations." Hagop Kaplanyan, born in 1948 in the Armenian Quarter of Jerusalem, graduated from Bir Zeit University and The American University of Beirut, where he acquired experience in photography, posters, pamphlet design, and painting. The titles of his enamel and oil works in the exhibit were "Palestinian Embroidery Motif," "Amulet," "Landscape II," and "Grandfather."

Isam Bader, Vira Tamari, Abed Tamman, Ali Bardawil, Hashem Kaleb, and Kamal Al-Mughanny are additional visual artists whose works deal with various facets of Palestinian nation building.

The dilemma of traditional versus radical tendencies, continuity versus change, typically features, on the one hand, nostalgic and sometimes dramatic portrayáls of the Palestinian peasant, such as Kamal AlMughanny's "Thirst." On the other, Mansour's "Development" expresses the need for modernization, illustrated in this case by themes related to science and technology (see Figures 2 and 3 ).

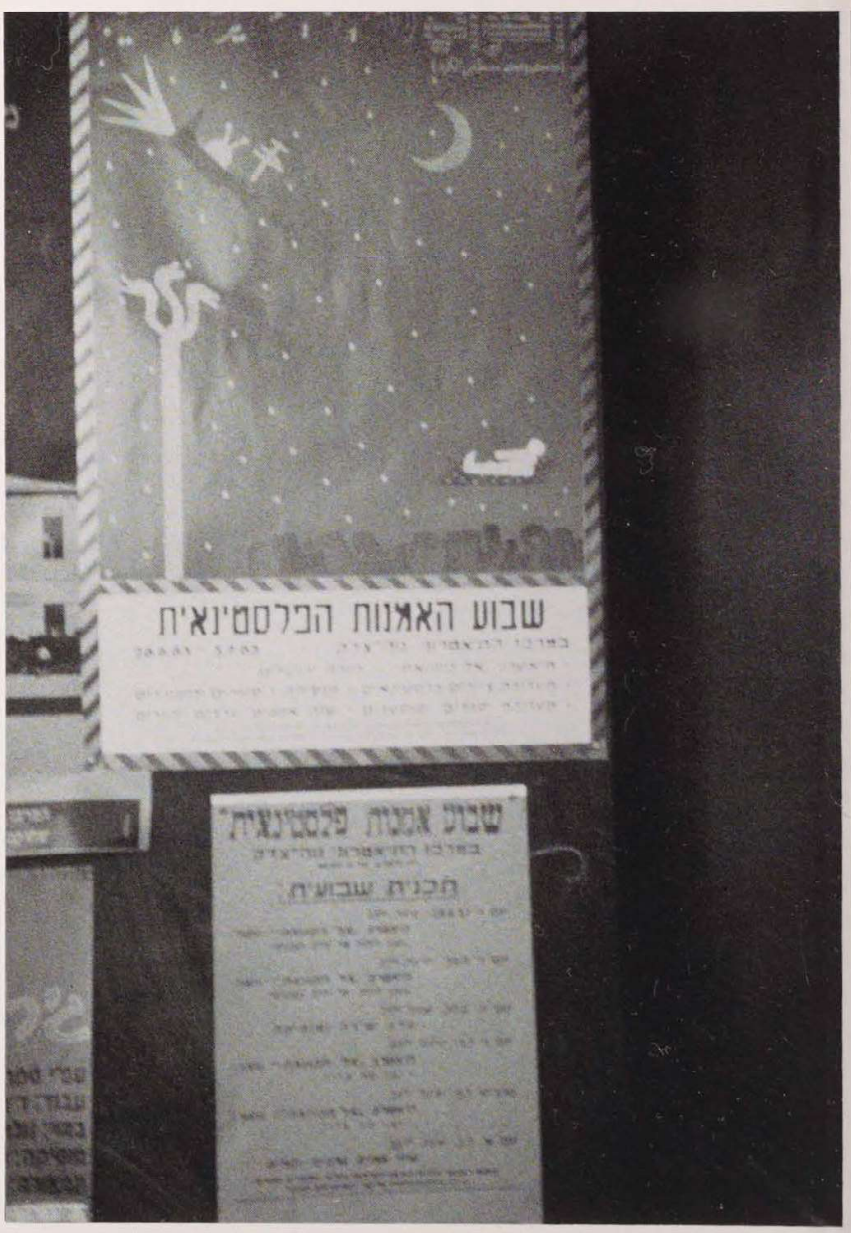

Figure 1 Color print.

The role of religion in the visual portrayal of the continuity-modernity dilemma is surprisingly modest. It appears rarely in works by well-known artists and its appearance is usually connected with nationalist motifs, such as the poster which depicts the imprisoned Omar Mosque, with its golden dome (Figure 4).

This modest emphasis on religion, in times of Islamic upsurge, can be explained on several grounds. It is true that some religious dimensions exist in Palestinian nationalism: the mosque and the pulpit still are integral features of the West Bank's social and political life, with particular reference to the South, in all-Moslem cities such as Hebron and its surroundings. Moreover, the High Islamic Council, with headquarters in Jerusalem and branches in the periphery, is still the only nationwide organization which operates legally in the West Bank with a considerable following. And clandestine political-religious bodies, such as those inspired by the ultra-conservative Moslem Brotherhood have had some success, as 


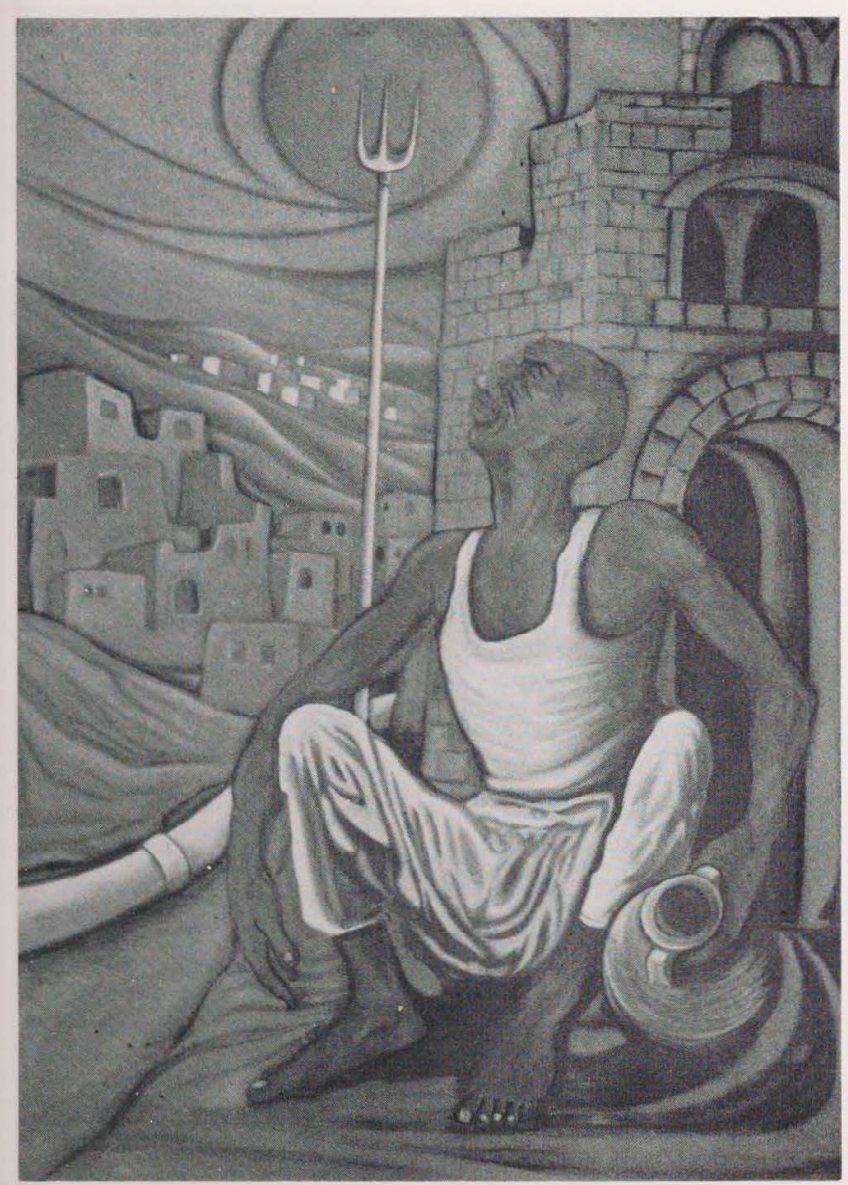

Figure 2 Kamal Al-Mughanny. "Thirst." Postcard.

illustrated by the surprising victory of a militant religious organization in the 1981 election of the Nablus Student Union.

On the other hand, the religious structure of the West Bank is not monolithic and includes Christians of various denominations, with a considerable amount of power, whereas among the Moslems, the relatively moderate Suni sect prevails, in contrast with the extremist Shiites in Iran and elsewhere. Furthermore, the High Islamic Council is supported financially by Jordan, being identified with one of the political streams and thus being out of the national consensus, or at least prevented from being impartial. The small size, geographic position, and historical background of Palestine as a cultural crossroads have probably increased its exposure to modern and secular values during generations, thus having weakened religious influence. Finally, the religious establishment in the West Bank has been tightly controlled by the Israeli authorities, its influence being curbed to a large extent.

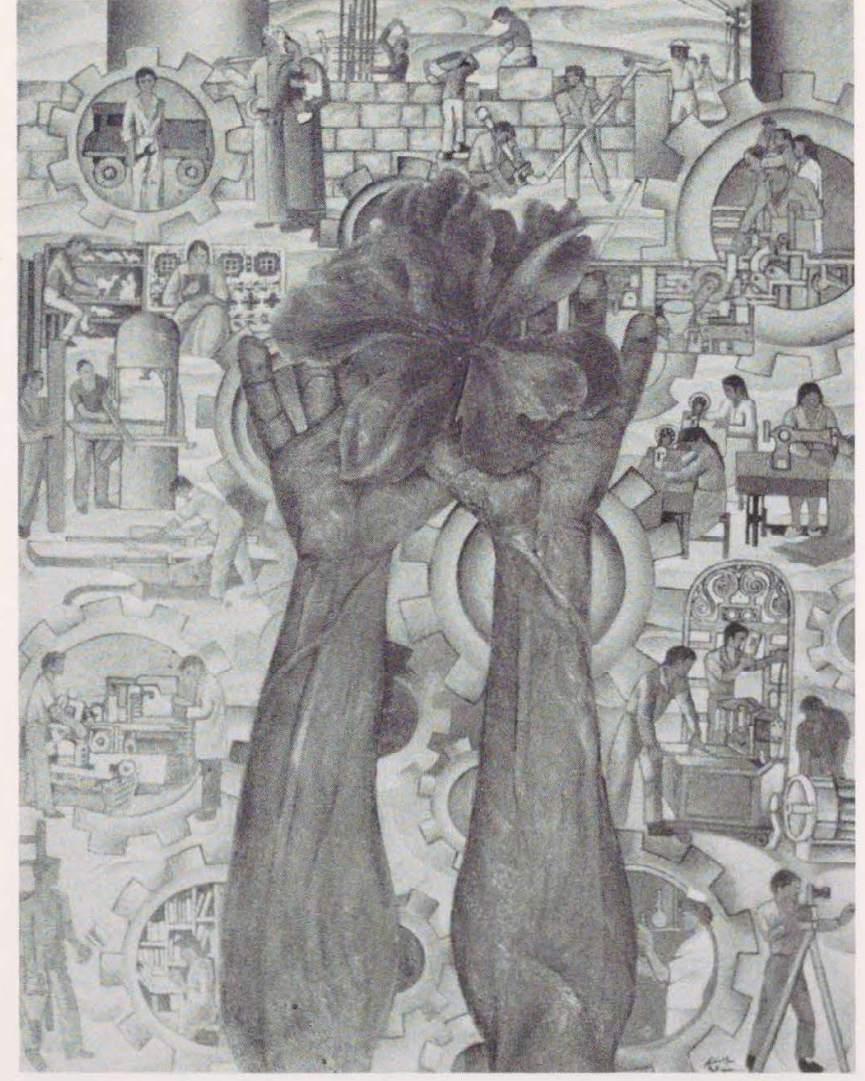

Figure 3 Suleiman Mansour. "Development." Postcard.

The dilemma of Pan-Arab and Pan-Islamic versus Palestinian nationalism, and the definite support of the latter by the majority of the population, is clearly expressed by Palestinian artists. The resentment with the performance of Arab countries - well illustrated by statements such as "We have learned that the help given by the leaders of the Arab States is limited and goes up to a point" (Lesch 1980:95) —has followed events such as "Black September" (of 1970), whereby Jordanian forces crushed the attempt made by the PLO to establish a state-within-a-state in the kingdom, devastating Jordanian-Palestinian relations Bitterness and anger are clearly expressed in Kamal Al-Mughanny's "Tal Alzaatar," which refersto the 1976 massacre of Palestinians, performed by rightwing militias, who were allowed by Syrian forces stationed in Lebanon to besiege and destroy this large refugee camp near Beirut (see Figure 5). 


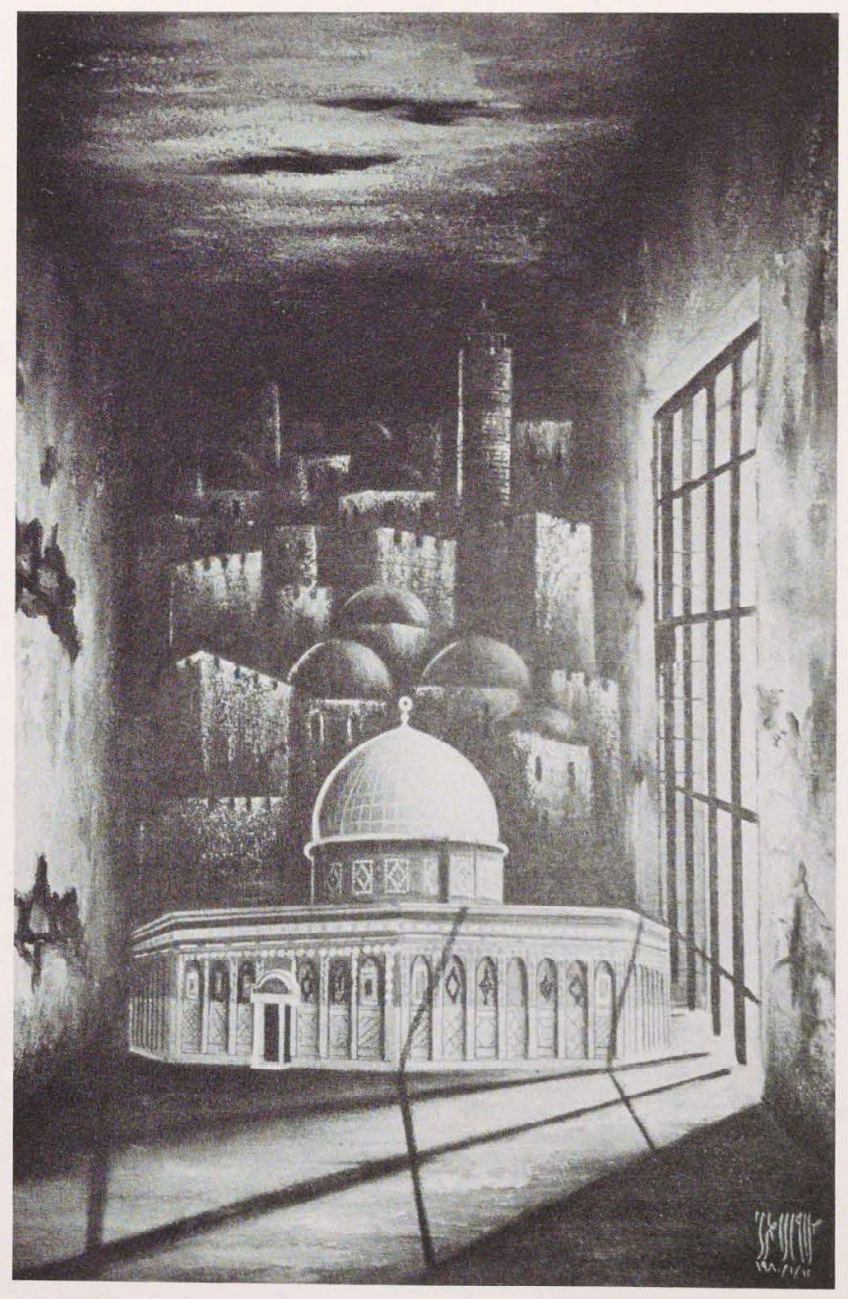

Figure 4 Color slide.

Palestinian symbols, on the other hand, appear in less dramatic yet strong terms, undoubtedly inspired by the PLO and including martyrdom, slogans, military insignia, and the Palestinian flag. This last motif appears almost invariably in most works of visual art Mansour's "Children in Jerusalem" features the redgreen-white-and-black flag in more than one context it is being held in the hands of young children, perhaps symbolizing the future. On another level, the flag appears together with other nations' colors, suggesting the legitimacy of Palestinian nationalism (see Figure 6). Other works, including Al-Mughanny's "Prisoner's Day," feature the flag in more subtle terms.

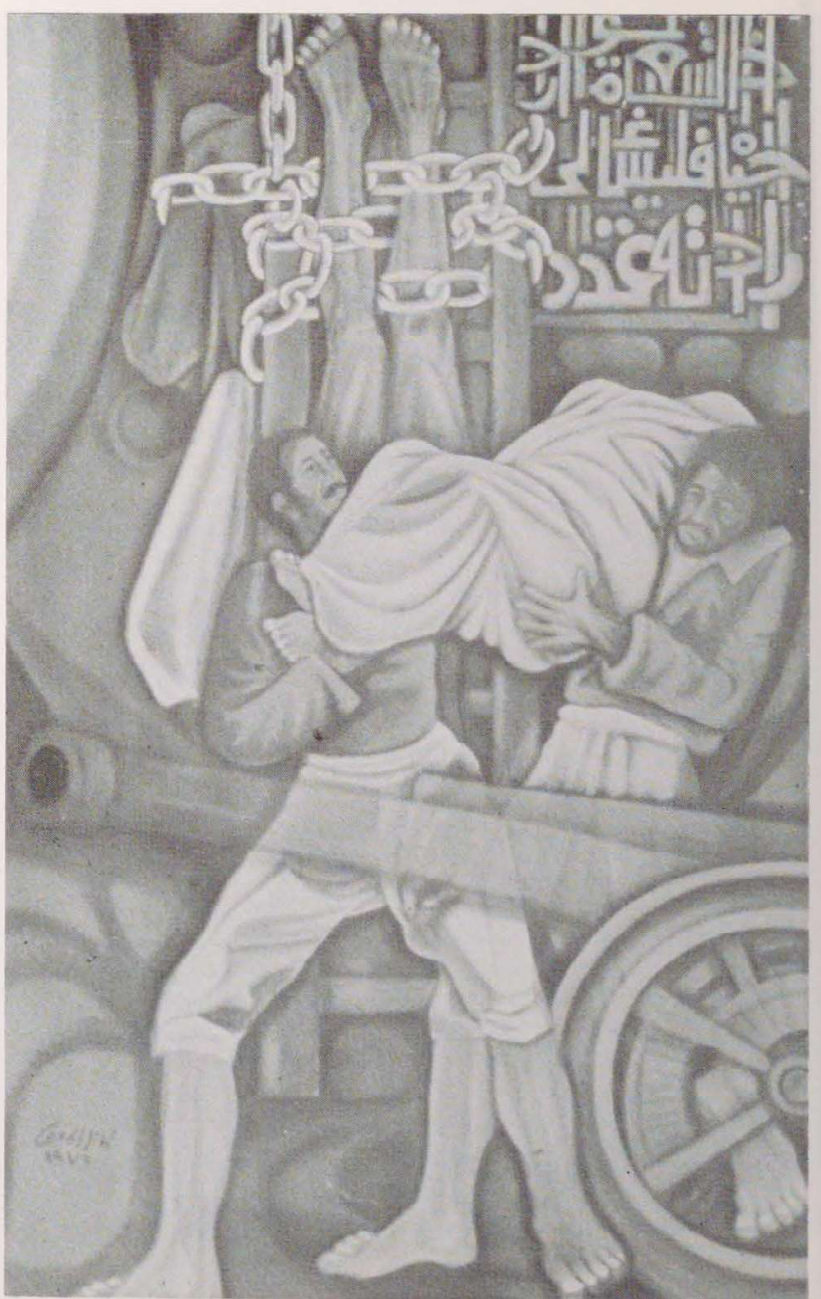

Figure 5 Kamal Al-Mughanny. "Tal Alzaa'tar." Postcard.

Problems of occupation have brought up one of the most serious dilemmas in Palestinian nation building, that of confrontation between the hope for a future in which the Palestinian nation will live in freedom and independence, and a present in which they must cope day by day with the pressures of occupation. In contrast with the ineffective outbursts of violence in the West Bank, in Israel, and abroad which were characteristic of the initial reactions to occupation, the concept of "Zumud" - standing fast-evolved as a temporary solution for daily existence. "Zumud" was adopted as a pragmatic and rational compromise between desperate, hopeless uprising and the feelings of undignified surrender. It has been a temporary formula, a "third way"10 for the solution of both conflicts 


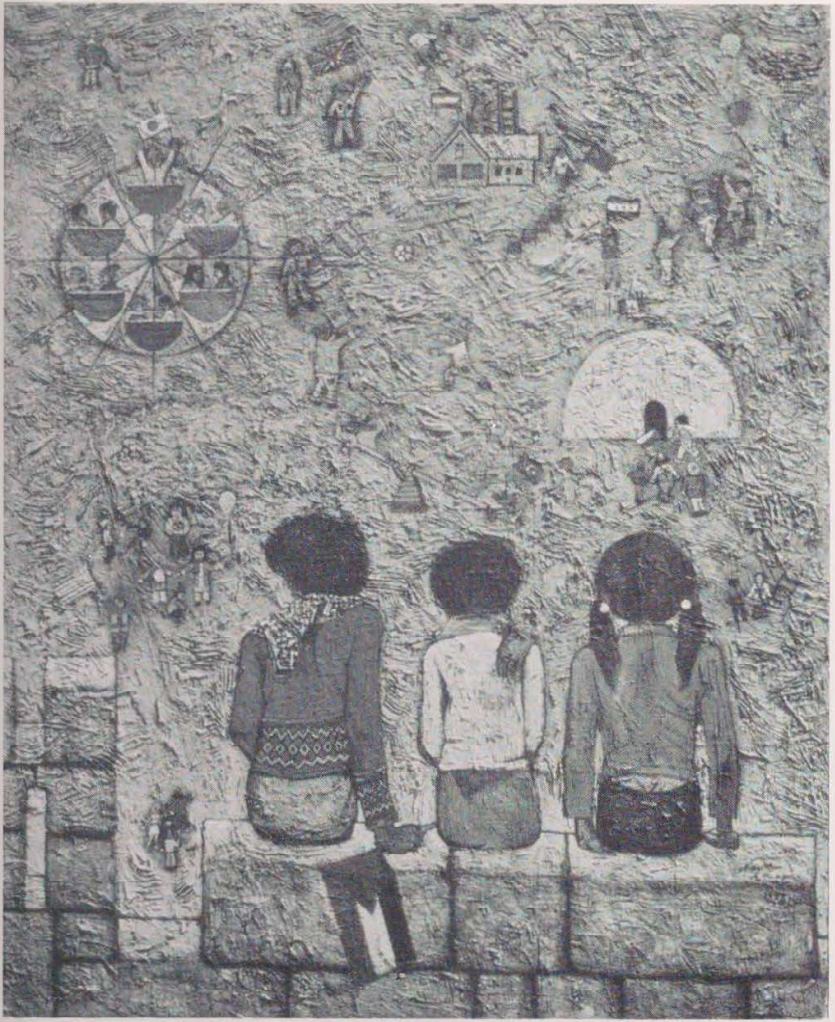

Figure 6 Suleiman Mansour. "Children at Jerusalem.' Postcard.

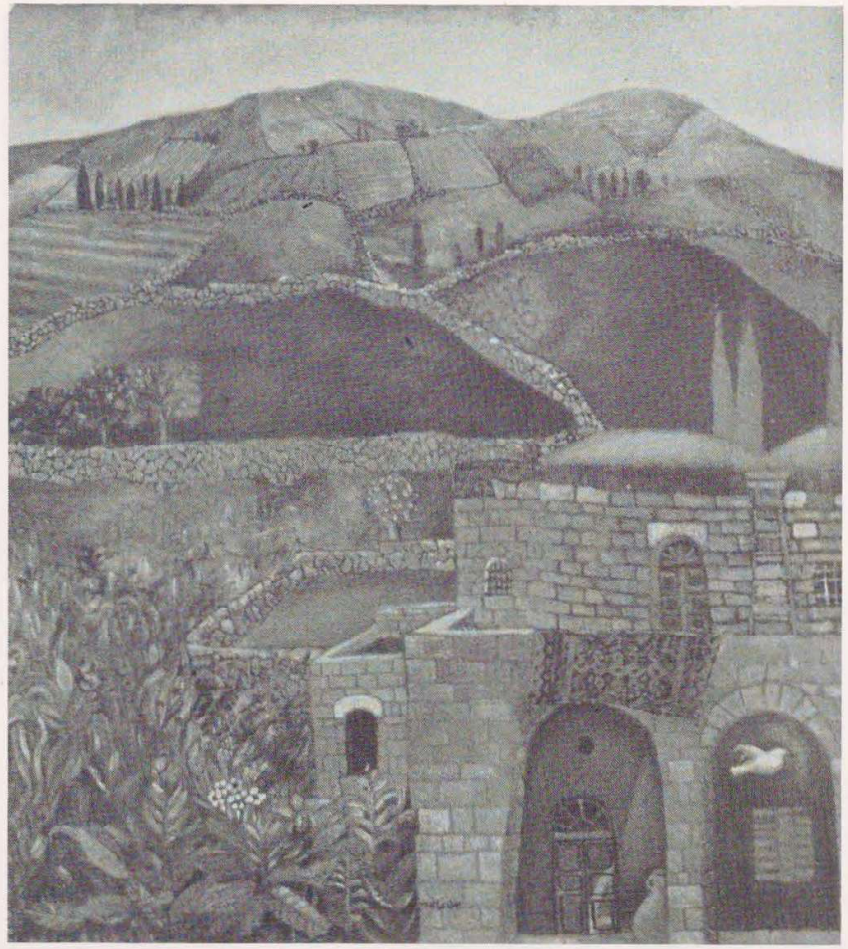

Figure 7 Nabil Anani. "From Halhoul." Postcard. in perception and acceptance of self, and day-to-day behavior vis-à-vis the Israeli presence.

The concept and its symbols have been dealt with extensively by Palestinian artists. The value of land is an outstanding example: "he who has no land has no honor," says a Palestinian proverb (quoted in Zogby 1983). Holding on to the land, "not to leave, not to turn your back to occupation"11 has become a primate, designed to prevent the repetition of the national trauma caused by the exodus of 1948. The conclusion of daily realities was that notwithstanding the symbolic value of boycotting and actively resisting the Israeli presence, they were secondary to holding on to the land. Settlement policies and facts, Palestinian interpretations of statements made by Israeli officials, and Jewish settlers' behavior increased the fear that Israel may use resistance as an excuse to embark on a policy of massive deportation and land expropriation. Whether justified or not, these feelings changed the initial reaction to occupation. The attitude that has prevailed as of the early $1970 \mathrm{~s}$ has emphasized compliance with occupation, without, however, accepting Israeli presence. Consequently, this type of "Zumud" has stood in contrast with the attitude of previous years, whereby any contacts with the authorities and with israelis in general were disap proved. Positive "Zumud" allows for working in Israel (including in the construction of settlements), to meet with Israelis and to participate in joint events, but it prohibits the selling of land, the receiving of compensation for expropriated land, or the acceptance of Israeli citizenship. Thus, land has become a major symbol in Palestinian literature, poetry, and art. Nabil Anani's "From Halhoul" is one example of this trend, which has been adopted by most of his peers (see Figure 7). 


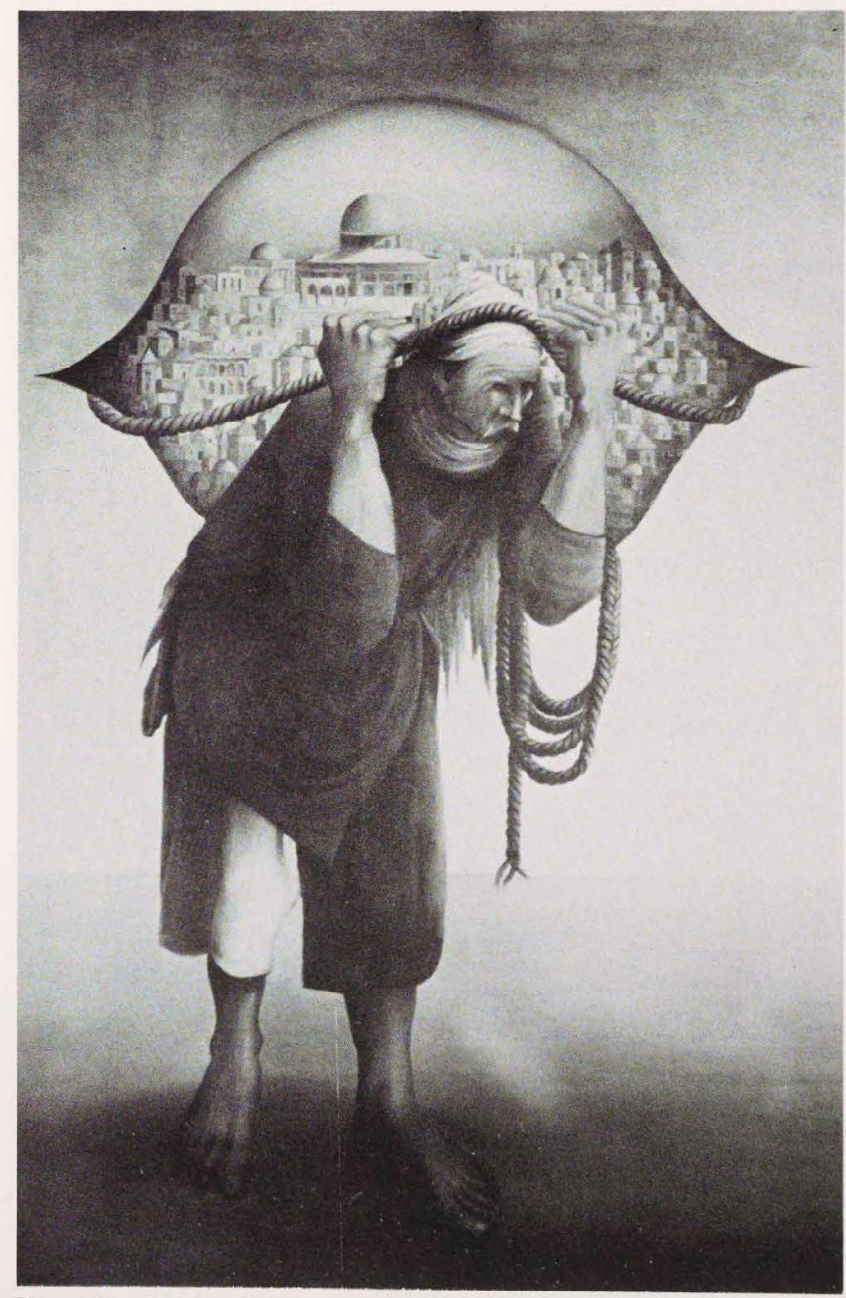

Figure 8 Color slide.

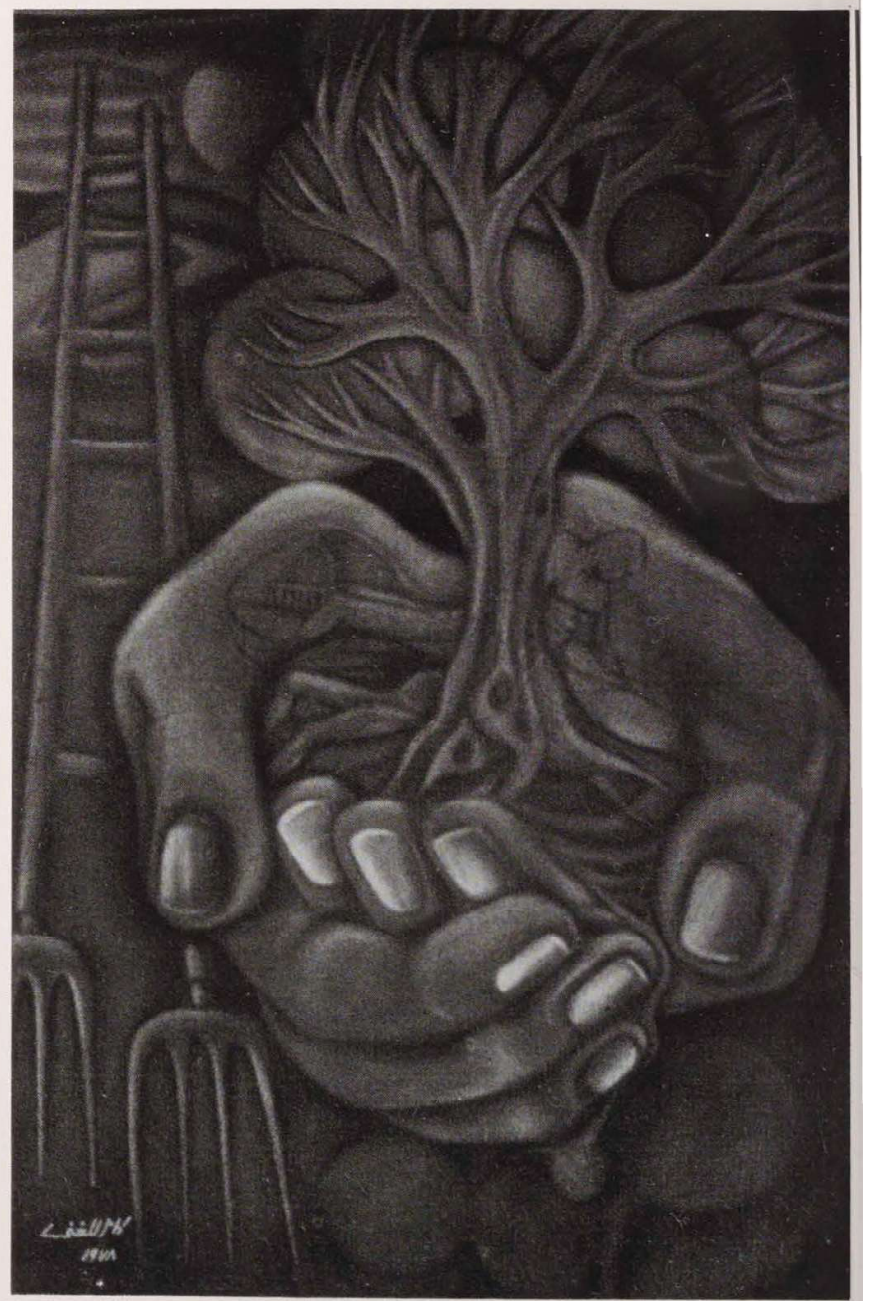

Figure 9 Kamal Al-Mughanny. "The People \& Land." Postcard.
Figure 9a Kamal Al-

Mughanny. "Jerusalem."

Postcard.

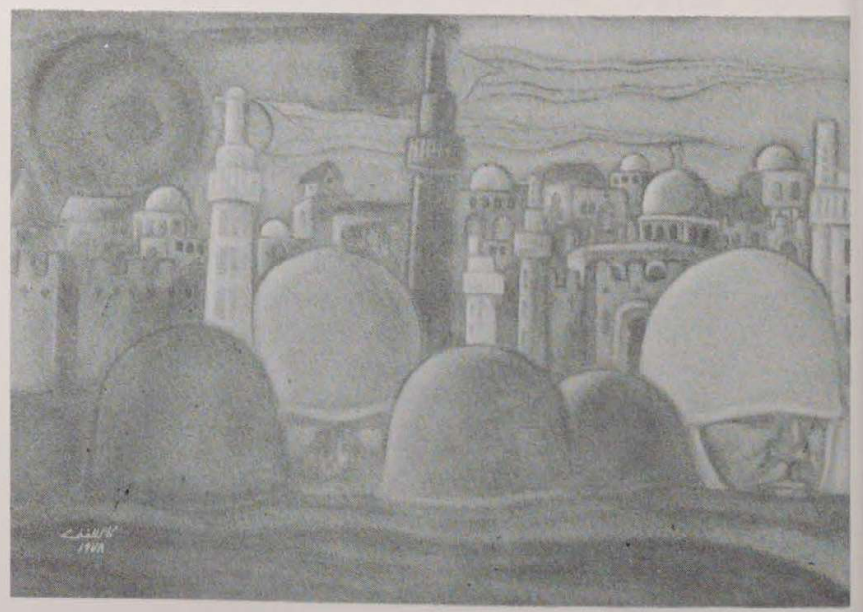




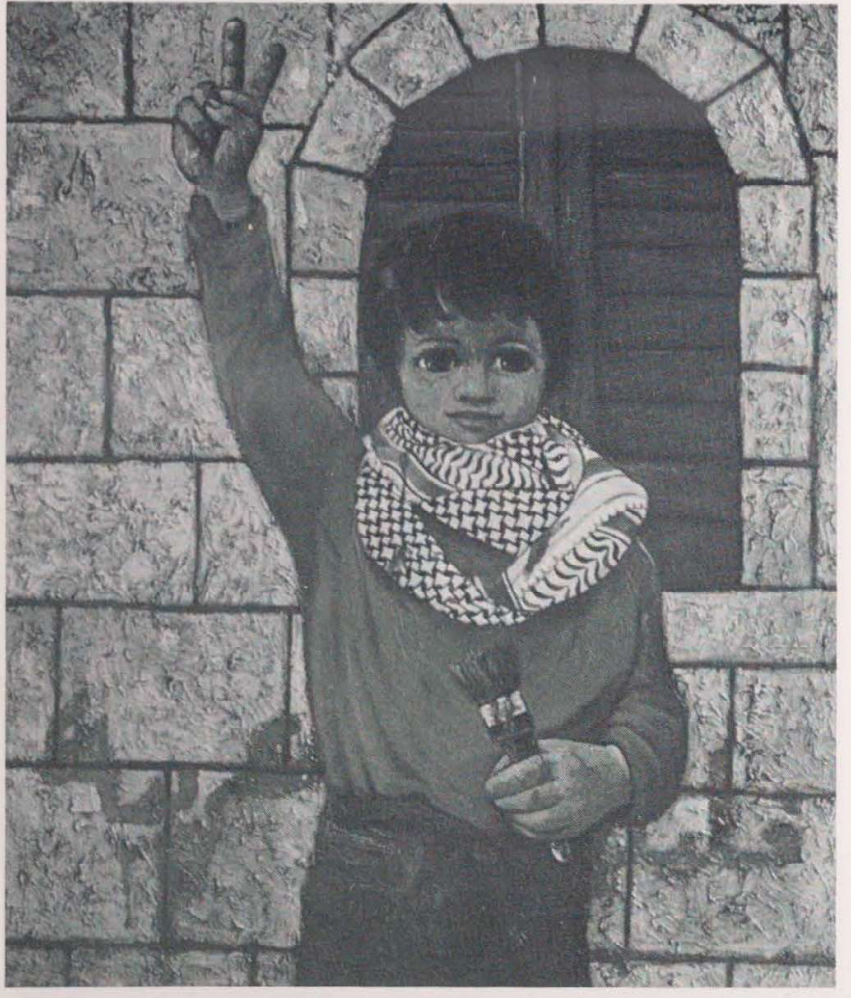

Figure 10 Suleiman Mansour. "The Future." Postcard.

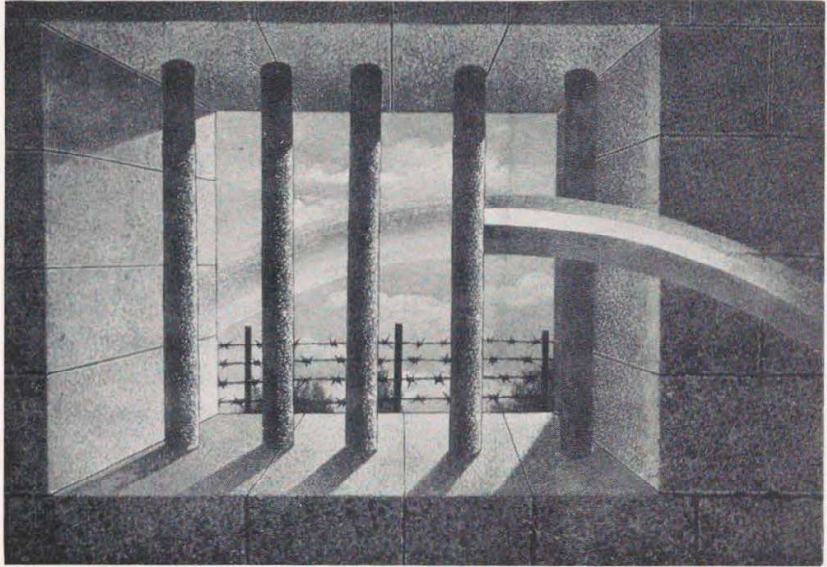

Figure 11 Suleiman

Mansour. "Hope."

Postcard.
Figure 12 Suleiman

Mansour. "Prisoner's

Day." Postcard.

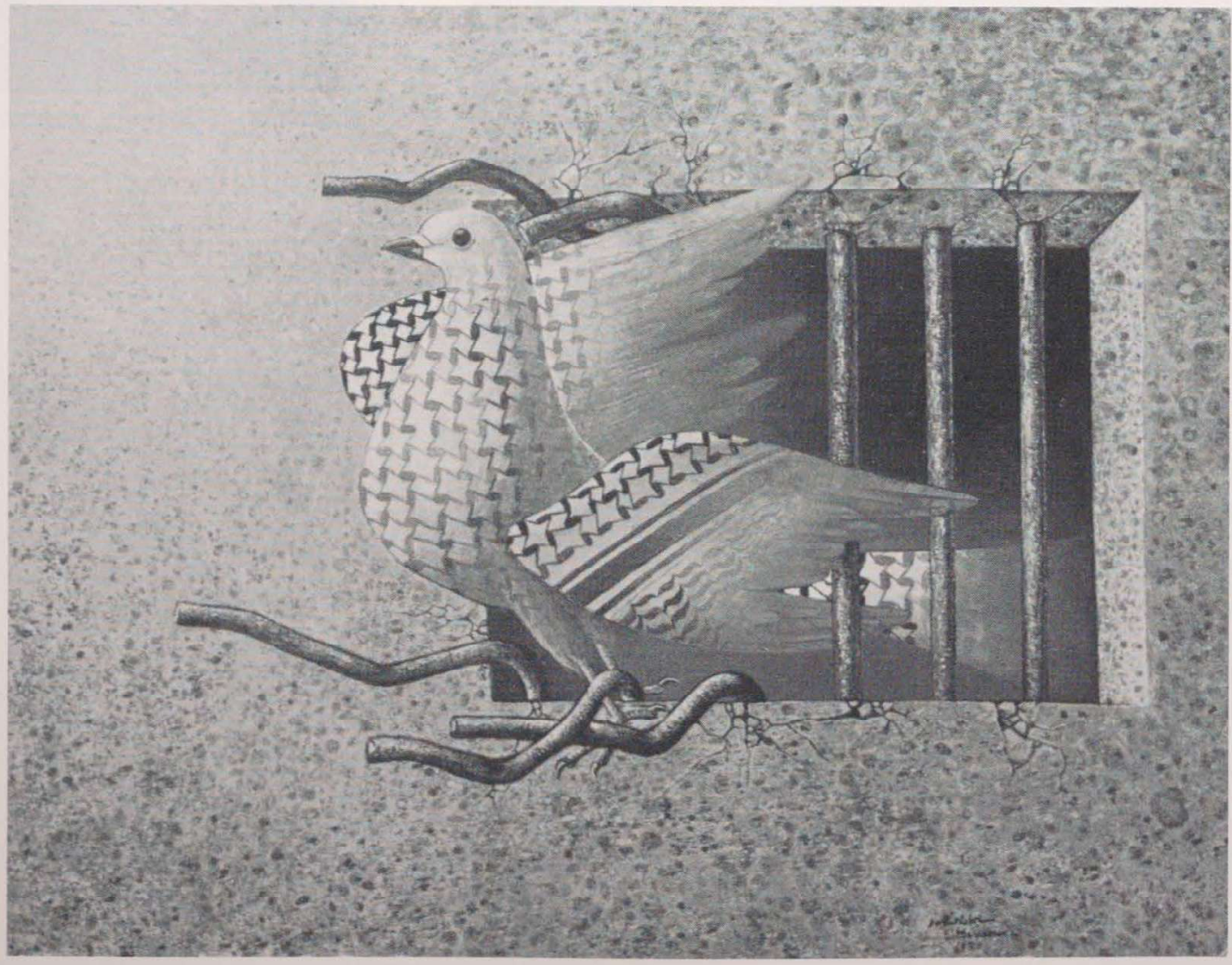


This outlook has been supported by a historical perspective. Based upon two hundred years of the Crusaders' hold on Palestine and 130 years of French rule in Algeria, hopes have been expressed on the temporary nature of the Israeli presence and on the prospects for a brighter future. Thus the meaning of the past not just as a source of tradition but also as a symbol of the continuous ties between the Palestinians and all the historical and cultural values of their land have been illustrated in a very popular poster in the West Bank (Figure 8). And thus the concept of growing out of sacrifice is expressed in Al-Mughanny's "The People and the Land," inspired by the Nablus's poetess Fadua Tukan (Figure 9)

Uprising and resistance received a strong symbolic dimension in the perception of "Zumud," perhaps to compensate for the inability to act. "Jerusalem," by Al-Mughanny, points out the value of "Zumud" as a means of resistance, complying with Yasir Arafat's statement that "merely holding out for a day is a small victory" (see Figure 9A). ${ }^{12}$

Suleiman Mansour portrays some present actions that symbolize the future (see Figure 10) and dopicts hope and liberation (see Figures 11 and 12).

A final dilemma that deserves attention refers to the Palestinian woman. The two fronts on which she has been struggling and her role in all dimensions of nation building are well expressed by her appearance in roles related to tradition (Figure 13), partnership (Figure 14), captivity (Figure 15), martyrdom (Figure 16), and active resistance (Figure 17).

A more systematic content analysis (Shinar 1983) of 73 visual items, including 33 postcards, 14 posters, 2 calendars, and 24 paintings, features the following themes:

1. Heritage, tradition, culture

2. Religion, divine justice and protection

3. Land, agriculture, village

4. Development, institutional infrastructure, industry

5. Liberation, hope, growth, future, redemption

6. Suffering, torture, destruction, martyrdom

7. Occupation, captivity, Israeli settlement and annexation

8. Rebellion, resistance, struggle, action, revenge

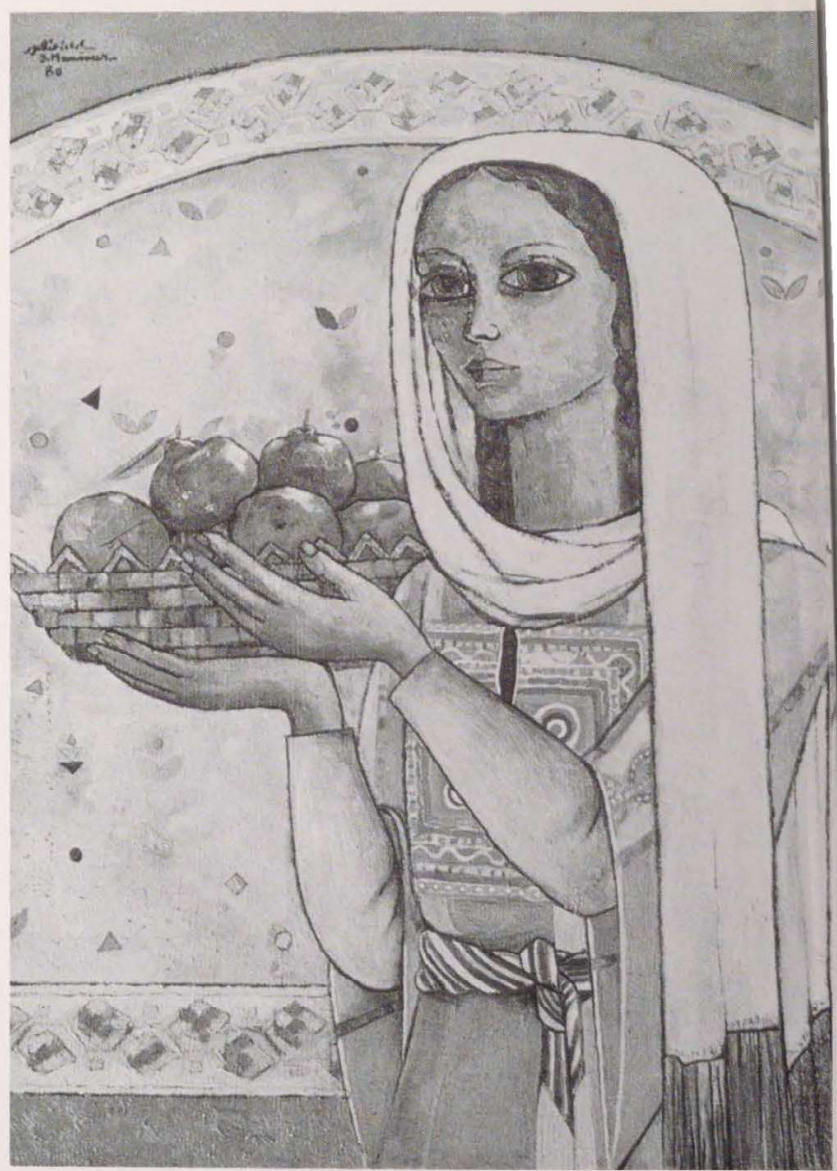

Figure 13 Suleiman Mansour. "Salma." Postcard. 


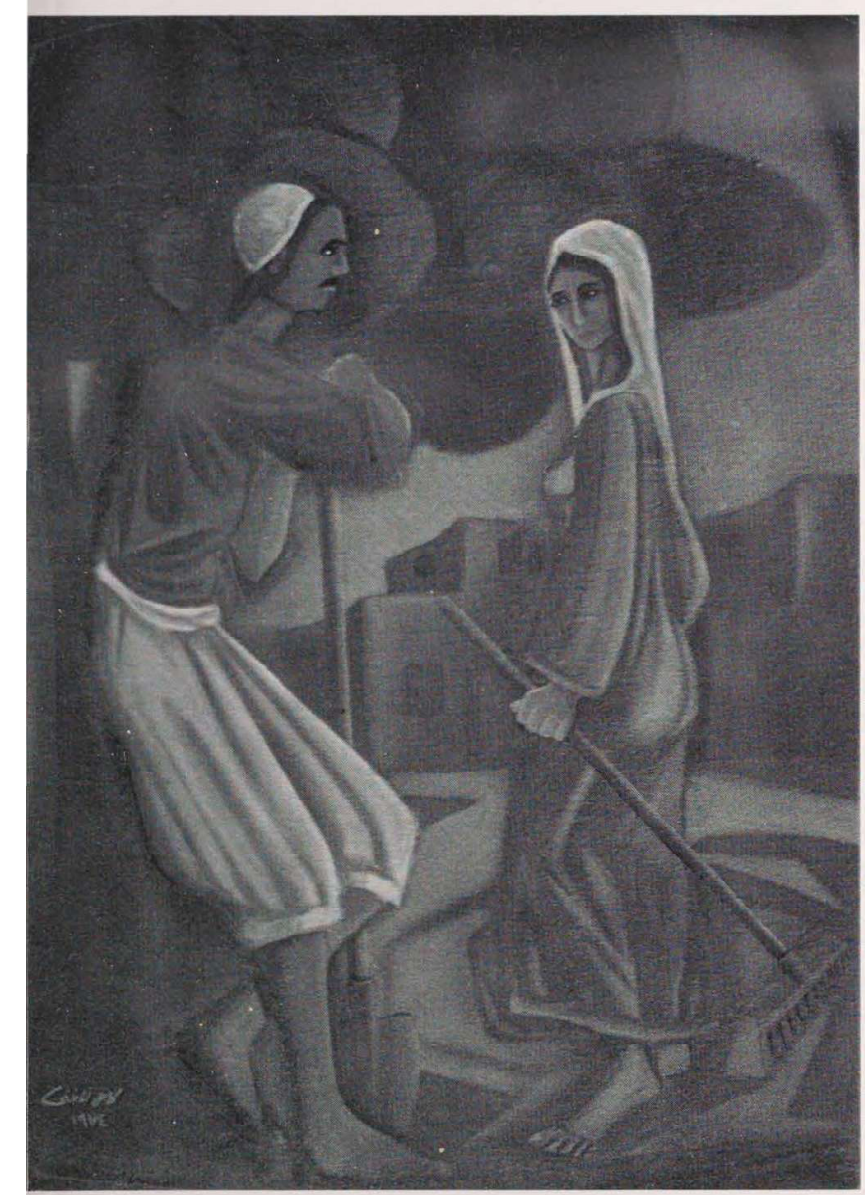

Figure 14 Kamal Al-Mughanny. "Partnership." Postcard.

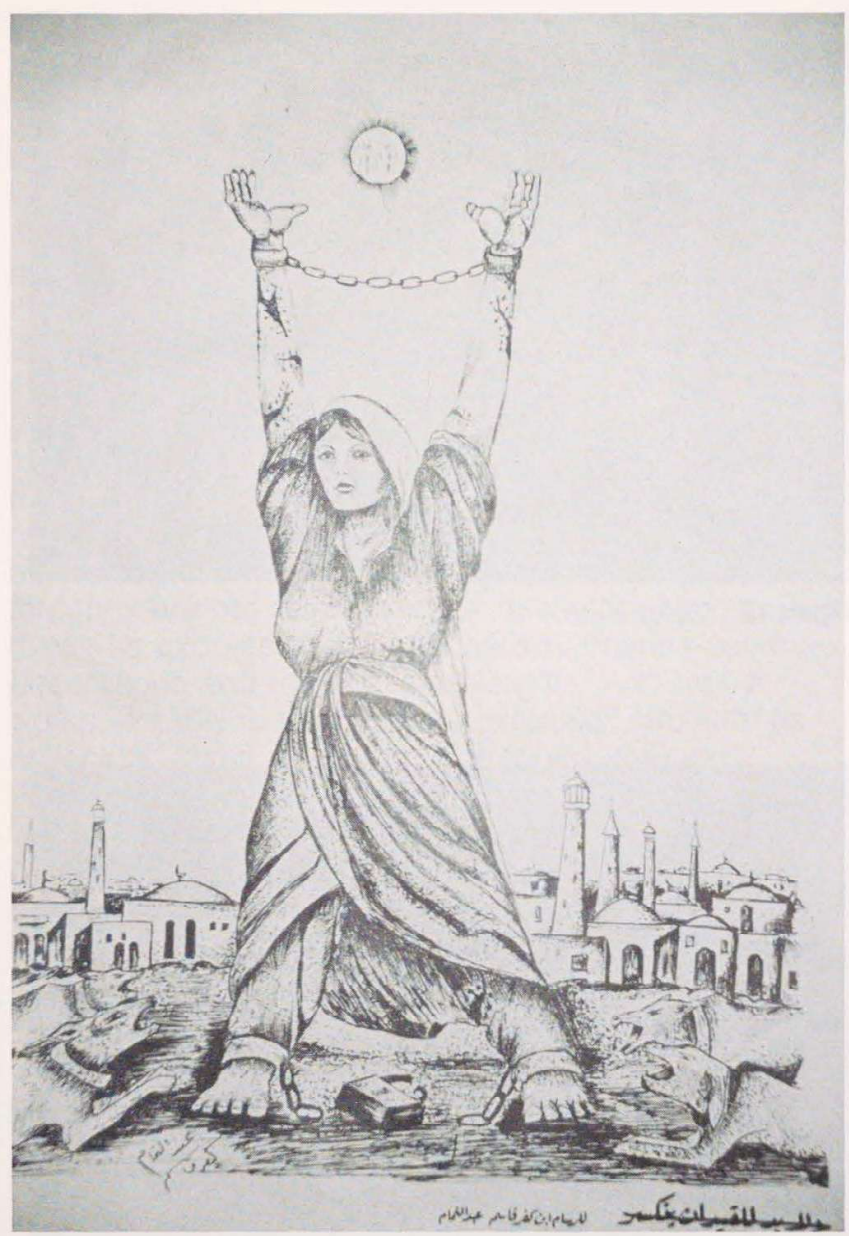

Figure 15 Color slide. 


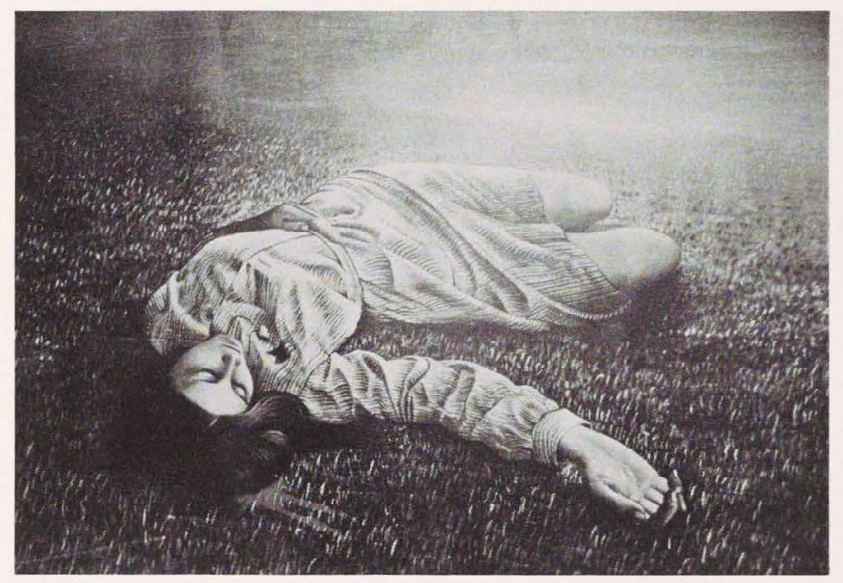

Figure 16 Color slide.

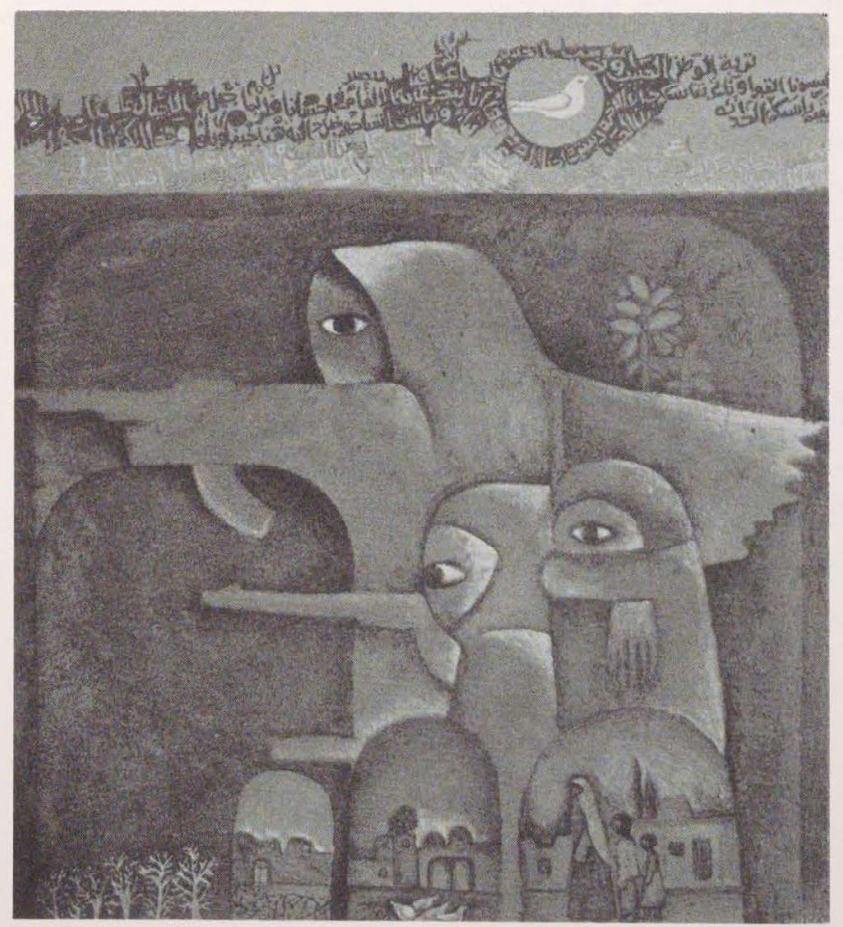

Figure 17 Nabil Anani. "Lebanon." Postcard.

\section{Style: The Palestinian Language of Revolt}

The language of Palestinian visual art features a twofold nature, perhaps revealing another facet in the search for identity. Symbols pertaining to an "international culture of revolution" are explicitly present in many works, notably by Al-Mughanny. His style seems profoundly affected by Mexican artists, such as Rivera and Orozco. The bold colors and the stark, almost cubist human forms contribute to create a dramatic impression, as presented in "Tal-Alzaatar," "Thirst," "Jerusalem," and "Prisoner's Day" (see Figure 18).

There is also an African presence in many works. The themes of national heritage and culture painted by Isam Bader, Vira Tamari, Nabil Anani, and Suleiman Mansour include many motifs that, in their simplicity and explicitness, resemble African handicrafts and sculpture. It seems that in the framework of the revolutionary style, Palestinian artists, when attempting to convey a sense of Palestinian heritage, strive to emphasize the non-Western villagelike nature of their work. The African atmosphere seems to have provided an appropriate vehicle for this purpose.

Abstract, surrealist style and some graphic forms comprise an additional type of international language, extensively used by Suleiman Mansour, perhaps as a result of his longer experience and Israeli training.

A combination of revolutionary influences is featured in a poster-size photograph of the first graduating class in Bir Zeit University, which is not shown here due to its inappropriate technical quality. The Black Power stretched arm-and-fist symbol, with the inscription "Palestine" diagonally across the poster, appears in the foreground. Among the graduates' pictures, in the background, one can discover small portraits of development, which resemble Israeli and other development language: planting a tree, a literacy class, a factory, and so on. On the other hand, a search for local symbolic identity is characteristic of many other works. "Salma," "Partners," "The Future," "From Halhoul," and Mansour's "Bread of Tabbon' are good examples of this trend, featuring folkloric embroidery, decorative motifs, handicrafts, tools, clothing items, foods, typical faces, and traditional moods (see Figure 19).

Moreover, even works that display foreign influences contain Palestinian symbols. Al-Mughanny's art, for example, has a predominance of the national colors - red, green, black, and white and the Palestinian flag appears in various types of disguise: in a worker's belt, in a woman's dress embroidery, or as in "Prisoner's Day," in a more explicit yet subtle form (see Figures 20 and 21). 


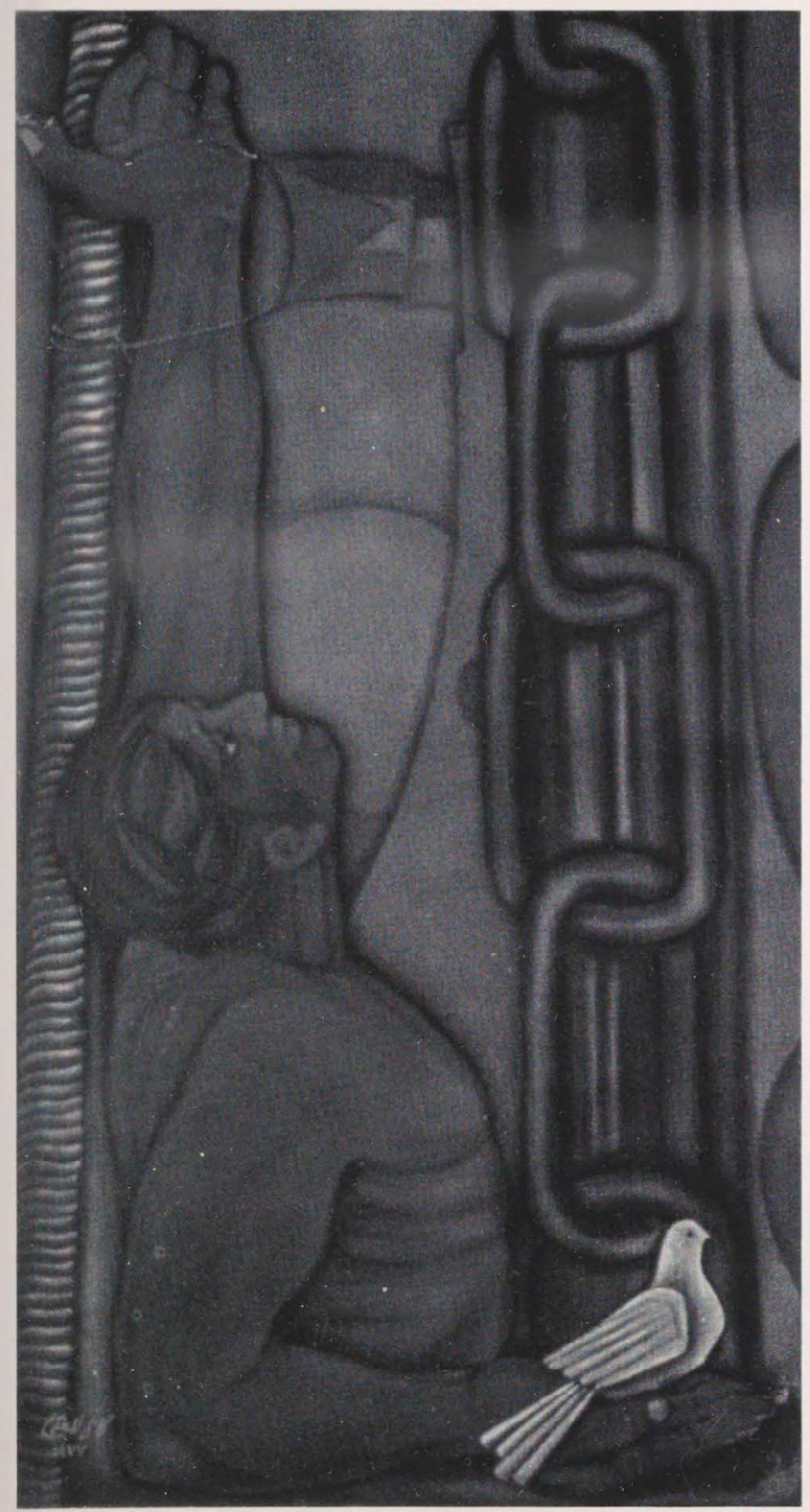

Figure 18 Kamal Al-Mughanny. "Prisoner's Day." Postcard.

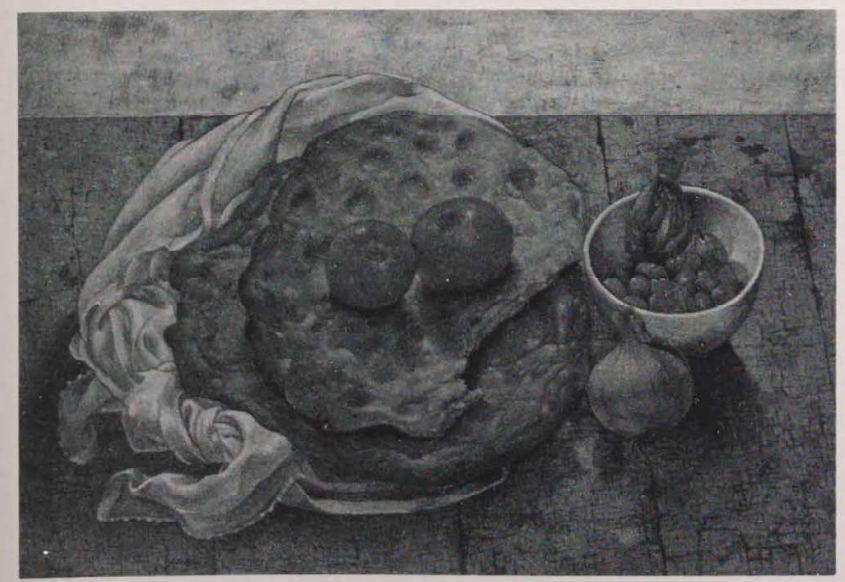

Figure 19 Suleiman Mansour. "Bread of Tabbon." Postcard.

\section{Distribution and Utilization}

Palestinian visual art is not divorced from the society and the circumstances in which its creation has been involved, thus following the principle expressed by Lev Tolstoy: "Art is a human activity consisting in this, that one man, consciously by means of certain external signs, hands on to others feelings he has lived through, and that others are infected by these feelings and also experience them" (quoted in Harap 1949). Most works of visual art in the West Bank are printed in posters and reproduced in postcards. They also illustrate publications' covers, calendars, leaflets, and T-shirts. Despite tight Israeli control, they are available in many stores in Jerusalem. Store owners and users of such visual items express the opinion that they are not purchased for aesthetic reasons, but rather as expressions of nationalism. Posters serve as decorations and make desirable gifts. And many works, notably in the form of postcards, circulate as collectors' items. They are exchanged among Palestinian youngsters in the same fashion that pictures of movie stars and sports champions are exchanged by Western youths. Adults send them through the post and otherwise, in Israel, in the occupied territories, and abroad, usually inside an envelope. The most common foreign destinations are Jordan, Syria, England, and the United States.

\section{Visual Communications and Palestinian Nation Building}

The considerable and varied production, circulation, and demand of visual arts in the West Bank suggest that they serve in nation-building functions. The contents and languages of such visual communications seem to be closely meshed in the sociocultural fabric of Palestinian society, thus satisfying the demand for institutional linkages between media of communication and their environment. Faulty linkages proved to be of crucial importance in the Iranian revolution, for example, in the relationship between control and functioning of mass communications. The Shah-controlled mass media did not manage to satisfy the masses' needs for reliable and acceptable symbols, coined by Geertz as representing "essentialist" values (Geertz 1975), with the result that effective control over the media was not translated into effective functioning (see Mowlana 1979; Sreberny-Mohammadi 1980; Tehranian 1980, 1982).

Palestinian visual expression seems to be compatible - at least structurally, although not necessarily in its content-with Khomeini's communications model, in that it is institutionally and culturally matched with the genuine needs of the population. Visual communications in the West Bank are part of a larger network that includes poetry, literature, theater, and the 
printed press, and on the other hand channels such as the family, the educational and occupational systems, community institutions, voluntary organizations the marketplace, rumors and other types of interaction (Shinar 1983).

The scarce amount of systematic empirical research allowed in the special circumstances of the West Bank-with constraints resulting from occupation procedures as well as from the consequent Palestinian reluctance to be exposed in such sensitive matters - at least suggests that visual communications are probably functional in the provision of two types of social and personal needs.

The first is the supply of cognitive and integrative tools necessary for enhancing public awareness and empathy, which can lead to identification and mobilization. This function has been documented in other cases (see Katz and Wedell 1977). The second function is related to affective necds and includes actionsubstitution and catharsis (see Katz and Gurevitch 1976). In a situation characteristic of all processes of liberation and nation building, which calls for social action, Palestinians have been hindered by occupation and by opting for "Zumud," from acting in meaningful ways. It seems that the alternative provided by visual and other symbols supplies emotional support, both in reflecting the situation and in compensating for the lack of action. This has been expressed in Rejeh Shehadeh's concept of "National Pornography," which he used in his book The Third Way: "When one lives in exile," says Shehadeh, "one thinks of the homeland in symbolic terms, as in pornography. The love of one's country is then expressed in its absence, and the process turns the homeland into something different. 'We the Jews', says Robert (Stone, whose interpretation of Jewish life in the Diaspora inspired Shehadeh), 'have had thousands of years in order to become expert pornographers; our yearning for this land includes plenty of rational symbols, which totally lack actual memories or pictures of its image in reality. When the Jews came back in the beginning of this century, they saw the land through these symbols. ...' Sometimes when I walk among the hills," says Shehadeh, "I find myself observing an olive tree, and it changes to become a symbol of the 'Zamadin,' of our struggle, of our loss. . . . This is probably the beginning of pornography ... national symbolism makes you think that way .... and it is strange that you should feel in exile, as a pornography addict, while living on your own land ... since occupation I think of our hills as 'virgins' tortured by Israeli bulldozers. ..." (Shehadeh 1982: 91-92).

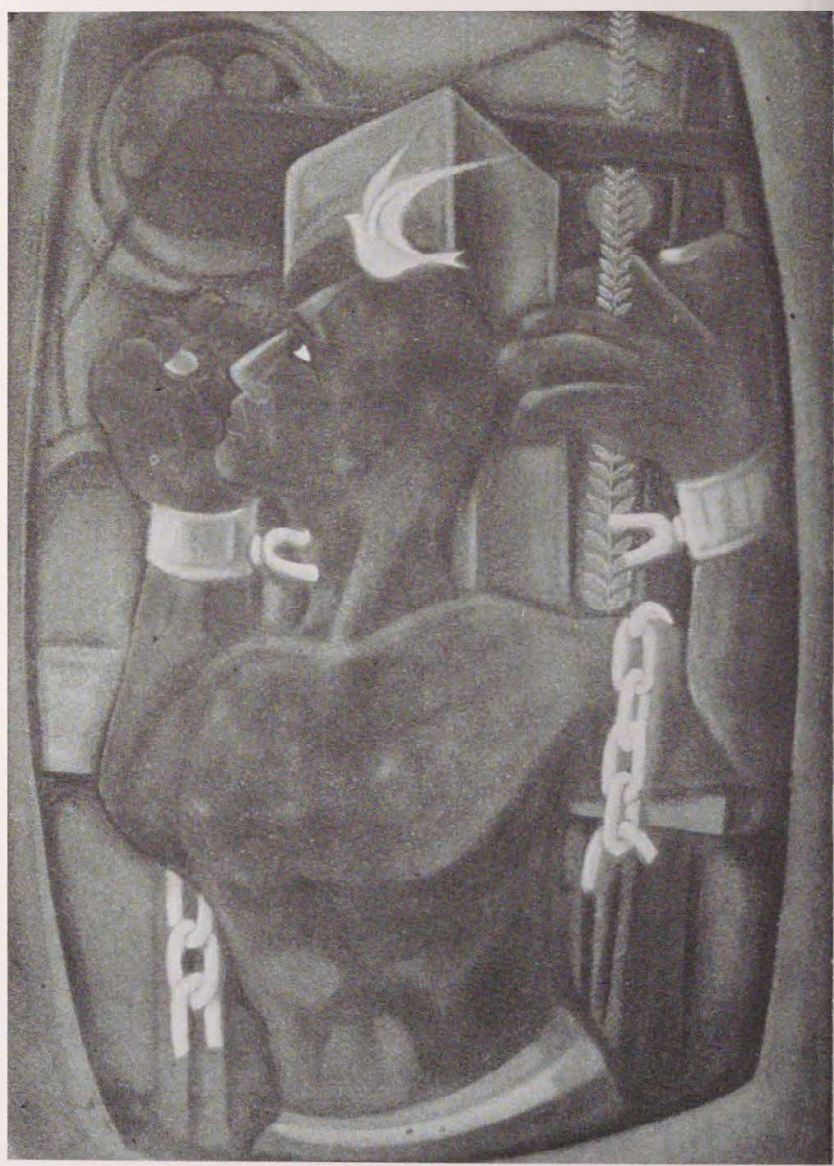

Figure 20 Kamal Al-Mughanny. "Settlement." Postcard

\section{Notes}

1 Mentioned in the "Framework for a Comprehensive Peace," appendix to the Camp David Agreement of September 1978, signed by Israel and Egypt in March 1979.

2 As issued by King Abdallah in March 1950; see Mishal 1978:1-2.

3 Quoted in Events, December 16, 1977

4 "Tahalichim Umegamot Bashtachim" [Processes and trends in the Territories], interview with Colonel Professor Moshe Maoz, Skira Chodshit [monthly survey], Israel Defense Forces, no. 5, May 1980 pp. 3-8.

5 "Arab Women," Minority Rights Group Report, no. 27, December 1975 , p. 15

6 Editorial, Al-Quds, June 5, 1972

7 Ann Lesch (1980:69) presents a detailed analysis of the connection between the October War and civil disobedience in the Wost Bank in the mid-seventies, and Moshe Dayan's policies of atomization.

8 Interview with Ibrahim Dakak, Salzburg, September 1979.

g This introduction was written before the Syrian-inspired revolt against Yasir Arafat's leadership of the PLO in late 1983.

10 A term coined by Rejeh Shehadeh, in his book by the same title, published in 1982 by Adam Publishers, Jerusalem (Hebrew).

11 Interview with a Palestinian senior journalist in Jerusalem, July 18 , 1981

12 Interview in "Filastin at-Thawra," August 1, 1973, translated in Jour nal of Palestine Studies, no. 9, Autumn 1973, p. 192. 


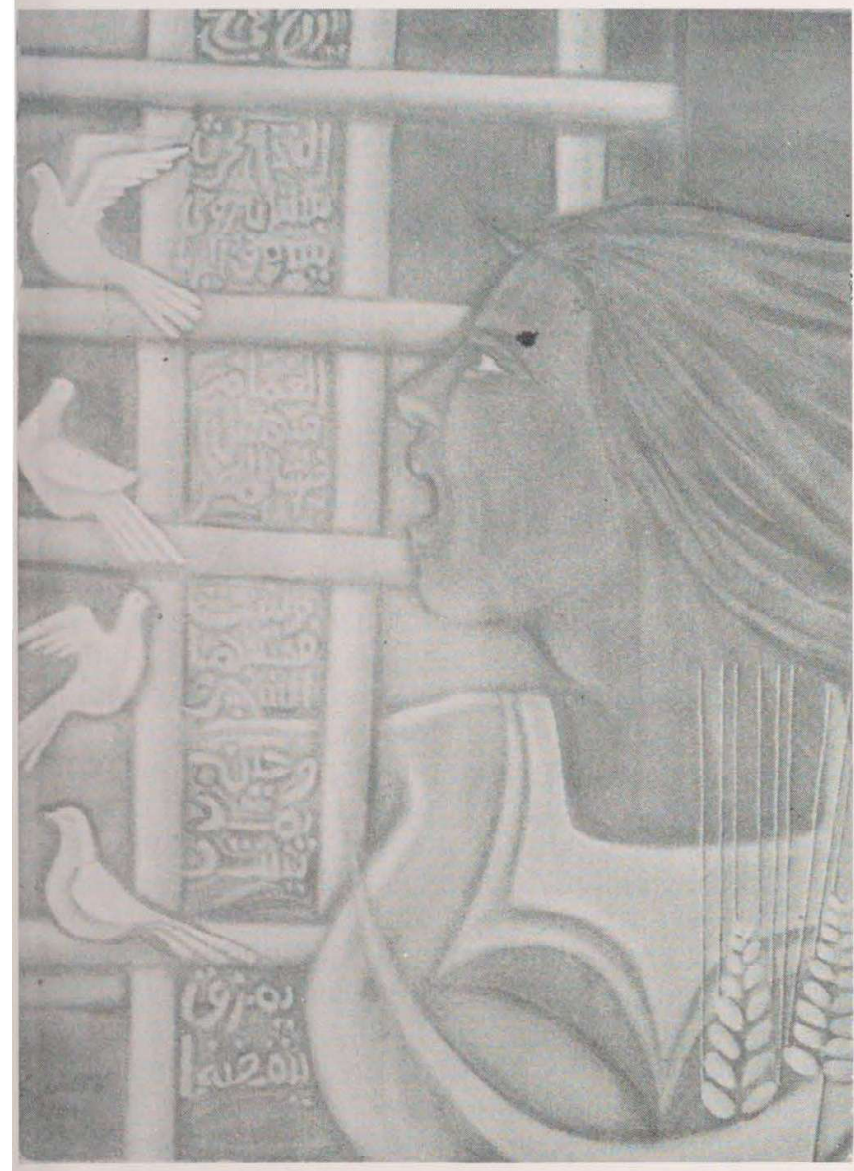

Figure 21 Kamal Al-Mughanny. Postcard.
- Lesch, A. M.

1980 Political Perceptions of the Palestinians on the West Bank and the Gaza Strip, Special Study 3. Washington, D.C.: The Middle East Institute

- Mansour, S

1977 Identity Among Palestinian Youth: Male and Female Differentials. Palestinian Studies 6(4): 71-89.

- Mishal, S.

1978 West Bank-East Bank. New Haven: Yale University Press

- Mowlana. $\mathrm{H}$

1979 Technology Versus Tradition: Communication in the Iranian Revolution. Journal of Communication 29(3): 107-112.

- Sayegh, R

1977 Palestinian Identity. The Middle East, April 1977

- Shaicovitch, B.

1973 Dialcctical Patcrnalism: Marx on the West Bank. New Middle East, April: 21

- Shehadeh, A.

1969 Fatah Does Not Speak for Democratic Palestine. New Middle East, March: 12

- Shehadeh, R

1982 The Third Way. Jerusalem: Adam Publishers

- Shinar, D.

1983 Communications in the West Bank. Research Report Jerusalem, July 1983 (Hebrew, mimeo)

- Sreberny-Mohammadi, A.

1980 Communications on Revolution in Iran. Paper presented at the Conference on World Communications, The Annenberg School of Communications, Philadelphia, May 1980.

- Tawil, R. H

1979 My Home My Prison. New York: Holt, Rinehart \& Winston

- Tehranian, M

1980 Socio-Economic and Communication Indicators in Development Planning: A Case-Study of Iran. Documents in Communications and Society, No. 5. Paris: UNESCO.

1982 Communications, Dependency and Dualism in Iran. Intermedia 3 (May):40-45.

- Zogby, J.

1983 Palestinian Identity and the Land of Palestine. Freedomways 23(2):118 125. Part 1

\section{References}

Ben-Porat, $Y$

1983 Sichot im Anwar Nusseibe [Talks with Anwar Nusseibe] Yediot Aharonot, January 7, 1983

Geertz, C.

1975 The Interpretation of Cultures. New York: Basic Books

Hamad, J.

1971 Palestinian Future: New Directions. New Middle East, August: 1619.

Harap, L.

1949 Social Roots of the Arts. New York: International Publishers. Jiryis, S.

1977 On Political Settlement in the Middle East: The Palestinian Dimension. Journal of Palestine Studies 25 (Autumn): 3-25.

Katz, E., and M. Gurevitch

1976 The Secularization of Leisure. London: Faber \& Faber. Chap 13.

Katz, E., and G. Wedell

1977 Broadcasting in the Third World. Cambridge, Mass.: Harvard University Press.

Klug, A. L

1979 Palestinian Identity and the Impact of the Israeli Occupation of the West Bank Between the June War of 1967 and the October War of 1973. Doctoral dissertation, University of Birmingham (mimeo). 